\title{
Preparation of Chitosan from Crab Shell and its Antibacterial Activity Against UTI Pathogens ${ }^{\dagger}$
}

\author{
A. Mini Varsini ${ }^{1, *}$, S. Abirami ${ }^{1}$, P. Revathi ${ }^{1}$, S. Sakthikavitha ${ }^{1}$ \\ 1 Department of Microbiology, Kamaraj College, Thoothukudi, Tirunelveli \\ * Correspondence: abisasi@gmail.com; \\ $\uparrow \quad$ Presented at International e-Conference on Bioengineering for Health and Environment (ICBHE 2020)
}

Received: 5.07.2020; Revised: 10.07.2020; Accepted: 12.07.2020; Published: 15.07.2020

\begin{abstract}
Chitosan was extracted from the chitin of crab shells. The process of deacetylation removes acetyl groups from the molecular chain of chitin. The yield of chitosan was $37.5 \%$, moisture content was $64.32 \%$, water binding capacity was $58.44 \%$. This study concluded that the FT-IR, NMR method is one of the best methods of determination of deacetylation. The crab shell extracted chitosan had significantly inhibited the pathogenic Escherichia coli, Proteus sp., and Klebsiella sp., isolated from UTI infected patients.
\end{abstract}

Keywords: Deacetylation; Deproteinization; chitin; biocompatible.

(C) 2020 by the authors. This article is an open-access article distributed under the terms and conditions of the Creative Commons Attribution (CC BY) license (https://creativecommons.org/licenses/by/4.0/).

\section{Funding}

This research received no external funding.

\section{Acknowledgments}

This research has no acknowledgment.

\section{Conflicts of Interest}

The authors declare no conflict of interest. 